\title{
Customer Satisfaction Promotion Strategies Based on Hedonistic /
}

\section{Utilitarian Attitude}

\author{
Rui Zhang ${ }^{1, a}$,Wenchao $\mathrm{Du}^{2, b}$ \\ ${ }^{1}$ Business School,Jianghan University,Wuhan, P.R. China \\ ${ }^{2}$ Central China Normal University,Wuhan, P.R. China \\ ax_zr@163.com, ${ }^{\mathrm{a}} 1296981460 @ q q . c o m$
}

\begin{abstract}
Keywords:Hedonistic attitude Utilitarian attitude Consumer satisfaction
\end{abstract}
Abstract:The consumer shopping attitudes was divided into hedonism / utilitarian from the psychological point of view in this paper.The paper also discussed how retail terminal can implement differentiated marketing and promote consumer satisfaction based on the analysis of consumer hedonism / utilitarian attitude.

\section{Introduction}

In recent years, the competition in the retail industry is becoming more and more intense, consumer demand appears polarized and personalized with the continuous segmentation of the retail market.As the retail industry maturities and develops, companies are increasingly focusing on consumer satisfaction research. Hedonistic attitude held consumers always feel the sense of pleasure when they are shopping, and prefer more experience、 fun and excitement (such as fashion, sports car, watches). Utilitarian attitude held consumers always make shopping as tasks, and prefer the basic functions (such as microwave ovens, electric fans, PC, etc.).

\section{Hedonistic attitude held consumers satisfaction promotion strategies}

For hedonistic attitude held consumers,go shopping means pleasure. So for them,the longer they stay in the mall, the more happiness they get, and the amount of consumption may also be higher. Therefore, we propose shopping malls should prepare all-round experience marketing strategy for hedonistic attitude held consumers.Besides maintaining consistent quality service, retail terminal should also develop new services and functions in order to make these consumers keep discovering "new pleasure" and stay fresh,thus the malls can win consumers as well as promote satisfaction . Compared with other industries, the large department stores have been at the forefront of the customer experience.Some large department stores with good locations and large business areas have achieved transiting to a shopping center, a multi-format store,combining "eat, drink, play, happy, shopping" all kinds of enjoyment in one shop, have changed the linear shops into vertical consumption "aircraft carrier" business model, and have become a new industry reflecting urban consumption features. In these multi-format "aircraft carriers", the consumer can get all the aspects of experience.

\section{Leisure and Entertainment Marketing}

Leisure and entertainment marketing means the enterprises skilfully put various marketing activities into leisure and entertainment, in order to achieve the purpose of promoting consumer purchases through attracting consumers by well-designed leisure and entertainment experience. 
Today's consumers are no longer satisfied with only boring shopping, instead they becoming more and more interested in leisure and entertainment, and pursuing more and more spiritual enjoyment. While shopping, consumers are increasingly demanding pleasant experience.They want shopping outside can be enjoyable every time. It requires that retail terminal should attract customers not only through a combination of product, but also need to consider increasing recreational activities besides the traditional service. Stimulate customer senses by entertainment, encourage consumers to experience joyfully in the store and consume. So now many large shopping centers have opened entertainment area,introducing restaurants,gyms, beauty salons, cinemas etc into it so that more consumer experience format can be provided. In addition,malls often organize interactive entertainment activities, such as New World Shopping Mall often holds the world's top luxury brand conference with special appearances of supermodels, fashion icons and celebrities etc; Wanda Shopping Centre and Chicony often have major brand promotion on their first floor, audience interaction 、 award-winning quiz 、improvisation etc often can drive the inside atmosphere.Thereby improving consumer satisfaction about decision making while shopping.

\section{Improve the level of selling services}

It is the pleasure through shopping that being liked by hedonistic attitude held consumers, they do not necessarily have to buy the products comparing to utilitarian attitude held consumers; it can be said that products variety, product attributes variety、 related attributes comparison of different products、 time restrictions are not enough to affect their satisfaction about decision making, on the contrary, the lack of these standards can't affect their satisfaction about decision making. It is because most hedonistic attitude held consumers haven't strong buying purposes, therefore purchasing guides' persuasion and patience is very important, purchasing guides need to sell products rationally with good attitudes. Some studies indicate that when consumers often feel guilty when buy non-practical goods, especially hedonistic attitude held consumers have more impulsive purchasing behaviors, so purchasing guide need to give adequate reasons for the buying, let hedonistic attitude held consumers feel free to buy,thus improving their satisfaction.

\section{Aesthetics Marketing}

Aesthetics Marketing focuses on meeting people's aesthetic, and provides pleasure 、 excitement and enjoyment to consumers via perception stimulation. Marketers can choose to use the beautiful elements、colors music shapes, patterns, etc., as well as the beautiful style, such as fashion, elegant, gorgeous, simple and so on, together with the beautiful themes in order to cater to the aesthetic taste of consumers, manifest the buying desires of consumers.Hedonistic attitude held consumers is often easy to revel in the fun of shopping, while an important factor affecting consumers purchase decisions is situation factor; so physical characteristics of the shopping places are important to hedonistic attitude held consumers. Thus we need to create a fairy-tale world. In addition to the elegant、 gorgeous mall decoration design,each shop counter also needs to be decorated to match the products, such as you buy shoes in the New World Shopping Center, you will have a different aesthetic experience. Shoes 、 ceilings v containers floors become integrated,Shoes with different styles, different colors are displayed from different angles, the levels are rich, three-dimensional senses are strong. The most eye-catching thing is that there is a unique fantasy tableaux of shoes area, colorful shoes-fitting sofas, body mirrors can let the shoes buying process of ladies like being on the stage. Through a series of experience ways attracting consumers to patronize, even if consumers do not necessarily buy, but the actions that they frequently enter into stores can gather the store popularity. With the deepening of the experiences, the possibility of potential consumers becoming into actual customers is enhanced. 


\section{Holiday Marketing}

The holidays or wage days are the best time for the hedonistic attitude held consumers to hit the malls every time.So on holidays, shopping malls need to be carefully arranged before the holidays, let manufacturers to increase the strength of new products, and held varieties of brand-related cultural activities during the holidays, such as fashion shows, singing and dancing competitions, the malls hold promotional activities related to the products, or brand roadshows, because this will attract hedonistic attitude held consumers most. So that consumers can go shopping in a cheerful atmosphere, at the same time adequate reasons can be provided to hedonistic attitude held consumers when they are shopping on holidays. Combining the several factors, if taking advantage of the holidays opportunity correctly,the satisfactions of hedonistic attitude held consumers can be promoted.

\section{Utilitarian attitude held consumers satisfaction promotion strategies}

Utilitarian attitude held consumers have little interests in shopping, have lower degrees of involvement in shopping, consider shopping as tasks and don't care shopping process. Utilitarian attitude held consumers may be relatively more loyal to brands ,but less to the malls. As long as the malls are near or convenient,they will go there and shopping. For such consumers, shopping malls should highlight how to grow consumers loyalty through differentiated shopping experience after meeting basic needs. Therefore, this study proposes that malls should adopt a differentiated experience marketing strategy for utilitarian attitude held consumers. In the shopping experiences, the buyers can get an immersive experience, good psychological feelings can bring psychological pleasure immediately. Thus, the malls with valuable experiences not only can win a place in consumers minds, but also can greatly enhance the value of their goods or services. For shopping malls, the specific approach is highlighting the added value of utilitarian attitude held consumers that they obtain when they are shopping while comparing with their competitors, so that consumers will feel even the goods are the same, due to the particular and better shopping experience, he / she would prefer to the malls, thereby improving satisfaction. The aspects of utilitarian attitude held consumers satisfaction promotions are as the following points:

\section{Improve the quality of services}

Utilitarian attitude held consumers want to quickly find the products they want at the retail terminal, and to compare the relevant products, then make a choice.The basic function of retail terminal is the ability to allow customers to easily buy goods. But because now the retail terminal area is widening,the types of goods are more and more, so it is not easy for consumers to find the exact location of the needed products in a short time. Therefore,the malls should provide shopping guide services, especially for utilitarian attitude held consumers, it is important to find the products quickly and easily. Not only the obvious signs should be set up ,but also shopping guide stations should be set up in prominent positions, and personal information services are needed too, so that any questions during consumers shopping process can be resolved quickly and efficiently; the payment process also need to be easy, simple and quick, so as to maximize the satisfaction of utilitarian attitude held consumers.

\section{Provide targeted services}

Because utilitarian attitude held consumers want to make choices fast and effectively among the products, therefore products variety, product attributes variety、 related products comparison are important factors that can affect satisfaction for hedonistic attitude held consumers,thus retail terminal need to make utilitarian attitude held consumers select their own products among a large number of products in a short time.Shopping guides need to observe and judge the intentions of 
consumers, seek for a proper time,because consumers need a independent and internal process to feel and emotionally experience the products. If contacting too early, consumers will not complete the process and receive emotional disturbance, resulting in difficult or psychological readiness; on the contrary, contacting too late, they may feel contempt, indifference, even reduce the interest and enthusiasm; in addition, shopping guides need to be responsible for their counter products, have a clear understanding, and very familiar with the differences between the products, so as to be able to help utilitarian attitude held consumers to make decisions quickly.

\section{Enhance the experience value of utilitarian attitude held consumers}

The literature and research find out that every consumer is holding both utilitarian and hedonistic attitude, just occupying different proportions. Therefore, we can try to make utilitarian attitude major-held consumers to increase hedonistic attitude after they go to the malls. The study found that if shopping with friends or family members, hedonism attitude will be relatively strengthened, so we can optimize the interior and exterior decorations of the malls, stereos, lights, weather and products displays etc., creating a cheerful atmosphere, which could increase the value of experience. At the same time we increase the amount of promotional sweepstakes for the whole family or many persons, because the utilitarian attitude of the utilitarian attitude held consumers can be affected when they are accompanied with family and friends, while consumer satisfaction can be promoted at the same time.

\section{Reduce buying concerns of utilitarian attitude held consumers}

Comparing to the hedonistic attitude held consumers, when utilitarian attitude held consumers are making purchasing decisions, they are faster, they want to buy goods in a short time, and they will worry about the purchase results that they have bought bad and unsuitable products after quick selections.On the one hand they make purchase decisions in a shorter time, on the other hand they are worried about the results. In this case, we need to require the quality of products in order to promote customer satisfaction,improve after-sales services as much as possible. For example, customers can change products even return products for free within a certain period, the customer feedback can be introduced more in the shopping guide services after the purchase, this method can reduce the utilitarian attitude held consumers' worry, thereby improving consumer satisfaction.

\section{Conclusion}

Today, we need to provide services according to the specific needs of different customers, to improve customers satisfaction, and to cultivate customers loyalty, and ultimately enhance the competitiveness of shopping malls.

\section{References:}

[1]Voss,Kevin E.,Eric R. Spangenberg,and Bianca Grohmann. Measuring the Hedonic and Utilitarian Dimensions of Consumer Attitude[J].Journal of Marketing Research,2003,40(8):310-20. [2]Anders Gustafsson, Michael D. Johnson, and Inger Roos. The effects of Customer Satisfaction, Relationship Commitment Dimensions,and Triggers on Customer Retention[J].The Journal of Marketing,2005,69(4):210-218.

[3]Mary Jo Bitner.Evaluating Service Encounters:The Effects of Physical Surroundings and Employee Responses[J].Journal of Marketing,1990,54:69-82.

[4]Kotler P.Marketing Management:Analysis,Planning,Implementation and Control,9th ed.,Englewood Cliffs,NJ: Prentice-Hall Inc.1999.

[5]Claes Fornell C,and David F. Larcker.Evaluating Structural Equation Models with Unobservable 
Variables Measurement Error[J].Journal of Marketing,1981,18:39-50. 